\title{
Curie Scoring System
}

National Cancer Institute

\section{Source}

National Cancer Institute. Curie Scoring System. NCI Thesaurus. Code C133462.

A semi-quantitative scoring system, developed at the Curie Institute in France, used for staging neuroblastoma patients at diagnosis and for response assessment following induction chemotherapy. Following whole-body 123I-mIBG scanning, osteomedullary involvement is scored for 9 skeletal segments plus a tenth score for soft tissue involvement. 